\title{
Concise Total Synthesis and Antifungal Activities of Fusaric Acid, a Natural Product
}

\author{
Bin Bin Huang, Ya Yi Liu, Peng Fei Zhu, Yi Cheng Jiang and Ming-An Ouyang *
}

Key Laboratory of Biopesticide and Chemical Biology (Ministry of Education), Fujian Agriculture and Forestry University, Fuzhou 350002, China; bbhuang@fafu.edu.cn (B.B.H.); yayiliu7180@163.com (Y.Y.L.); z15960505490@163.com (P.F.Z.); jiang1658517698@163.com (Y.C.J.)

* Correspondence: maouyang@hqu.edu.cn; Tel./Fax: +86-0591-87646115

Received: 4 August 2020; Accepted: 24 August 2020; Published: 25 August 2020

\begin{abstract}
The total synthesis of a natural product alkaloid fusaric acid (FA), which exhibits herbicide, fungicide, insecticide and even diverse notable pharmacological activities, was accomplished in four steps using commercially available materials. The synthesis, based on a unified and flexible strategy using 6-bromonicotinaldehyde as a common intermediate, is concise, convergent, practical and can be carried out on a two-gram scale. This approach could be readily applicable to the synthesis of its analogues. In addition, FA had a wide range of inhibitory activities against 14 plant pathogenic fungi in this study, which demonstrated that as a leading compound, and it has great potential to be further developed as an agricultural fungicide.
\end{abstract}

Keywords: total synthesis; 5-butylpicolinic acid; natural product; alkaloid; antifungal activity

\section{Introduction}

Plant diseases are the formidable enemy of agricultural production. According to the statistics of the Food and Agriculture Organization of the United Nations (FAO), the crop yield loss caused by plant pathogens is about $10 \%$ to $15 \%$ of the total output on average annually [1]. The use of fungicides against plant pathogens is a major means of ensuring crop production, so global agriculture has always maintained a strong demand for fungicides on the market. In the early 1970s, with the registration and widespread use of the systemic fungicide benomyl (Benlate), the problem of fungicide resistance became apparent. Now, significant fungicide resistance is a widespread problem in global agriculture. In this silent battlefield of fighting against the development of fungicide resistance, the most important and fundamental weapon that mankind can grasp is to accelerate the research of new structural compounds that can be used for the agricultural field, and further find new target sites and modes of action [2].

Fusaric acid (FA), chemically known as 5-butylpicolinic acid, is a natural product alkaloid, with low to moderate toxicity [3], isolated by Yabuta T. in 1934 from the secondary metabolites of Fusarium heterosporium that parasitizes rice [4]. A large number of research data showed that FA has diverse notable pharmacological activities, ranging from anti-hypertensive $[5,6]$ and anti-viral $[7,8]$ activities to anti-cancer effects $[9,10]$ and the treatment of Parkinson's disease [11,12]. As a kind of phytotoxin, FA and its derivatives also exhibited marked herbicidal activity $[13,14]$. It also has certain insecticidal activity as an important insect phenoloxidase inhibitor $[15,16]$. In addition, FA showed strong antifungal activity in both medical and agricultural fields $[17,18]$.

FA has been discovered for nearly 90 years, during which many synthetic approaches have been developed. Generally, according to the methods of establishing the target structures, these synthetic approaches can be classified into two categories: by constructing a pyridine ring via Diels-Alder type reactions (Scheme 1) [19-22] and by elaborating substituted pyridine intermediates (Scheme 2) [23-28]. 
The reported syntheses using Diels-Alder reactions either must be carried out under harsh conditions, or substances such as selenium dioxide $\left(\mathrm{SeO}_{2}\right)$ [21,23,29], gaseous hydrogen chloride ( $\left.\mathrm{HCl}\right)$ [19], potassium permanganate $\left(\mathrm{KMnO}_{4}\right)$ [24] and magnesium amalgam [24], which are both toxic to human body and harmful to the environment, were used, and these methods are not suitable for large-scale synthesis. Substituted pyridine intermediates designed and elaborated can readily facilitate the synthesis of FA and its analogs. Song et al. [27] prepared the key intermediate benzyl 5-bromopicolinate from raw material 2,5-dibromopyridine, and then synthesized FA through Negishi coupling, catalytic hydrogenation reaction and recrystallization purification. Tung et al. [28] prepared the key intermediates methyl (or ethyl) 5-bromopicolinate, then synthesized FA and its analogies via two-step reaction of Suzuki coupling and hydrolysis. We have practiced these two routes and found that the yield of Negishi and Suzuki coupling reactions was not satisfactory $(<15 \%)$ due to the ester moieties. Hence, a more practical and scalable approach with an easily accessible reagent is still highly desirable to synthesize FA and its analogues to facilitate further antifungal activity evaluations.

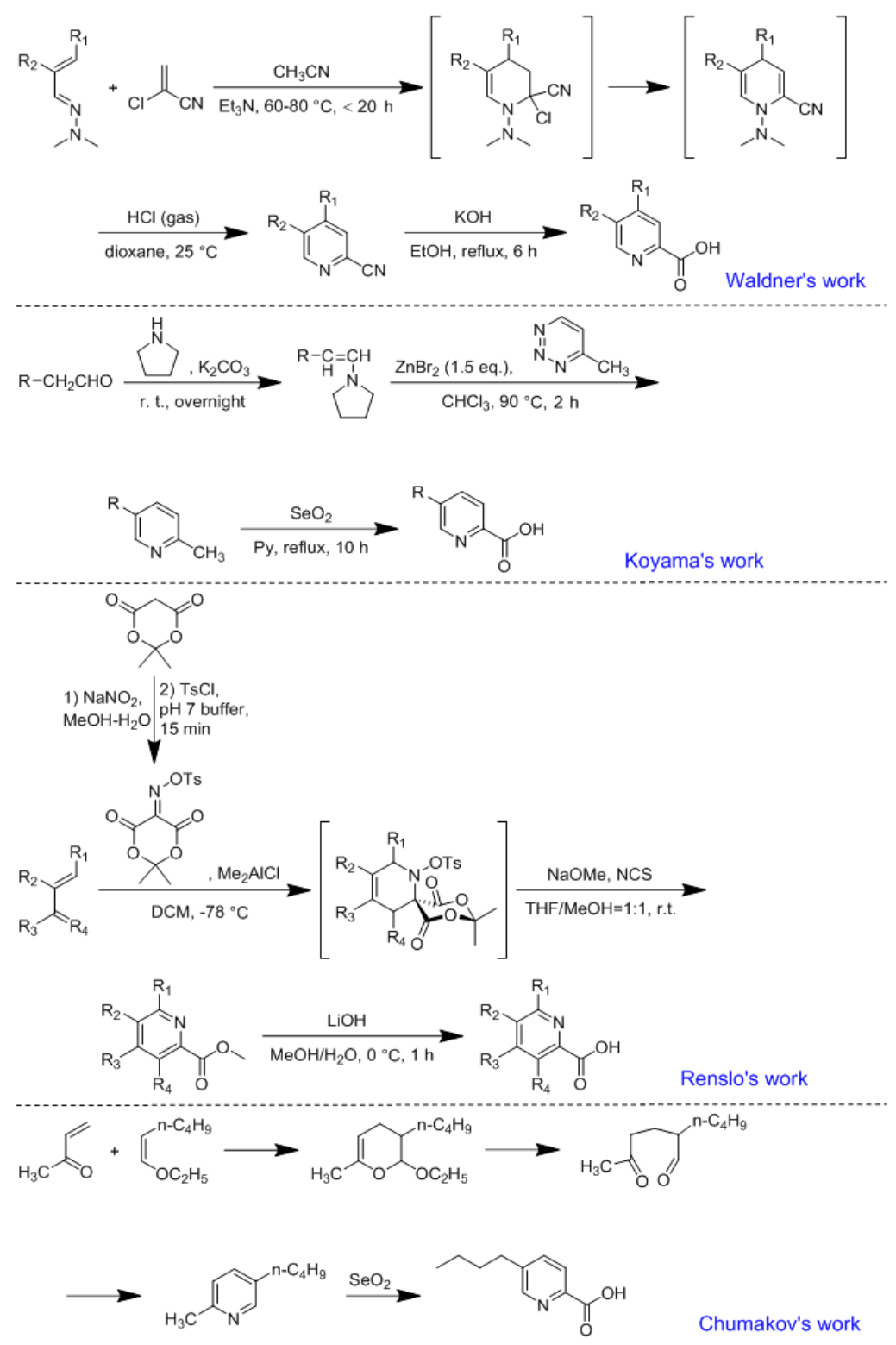

Scheme 1. Previous work for total synthesis of fusaric acid (FA) by constructing pyridine ring via Diels-Alder type reaction. 

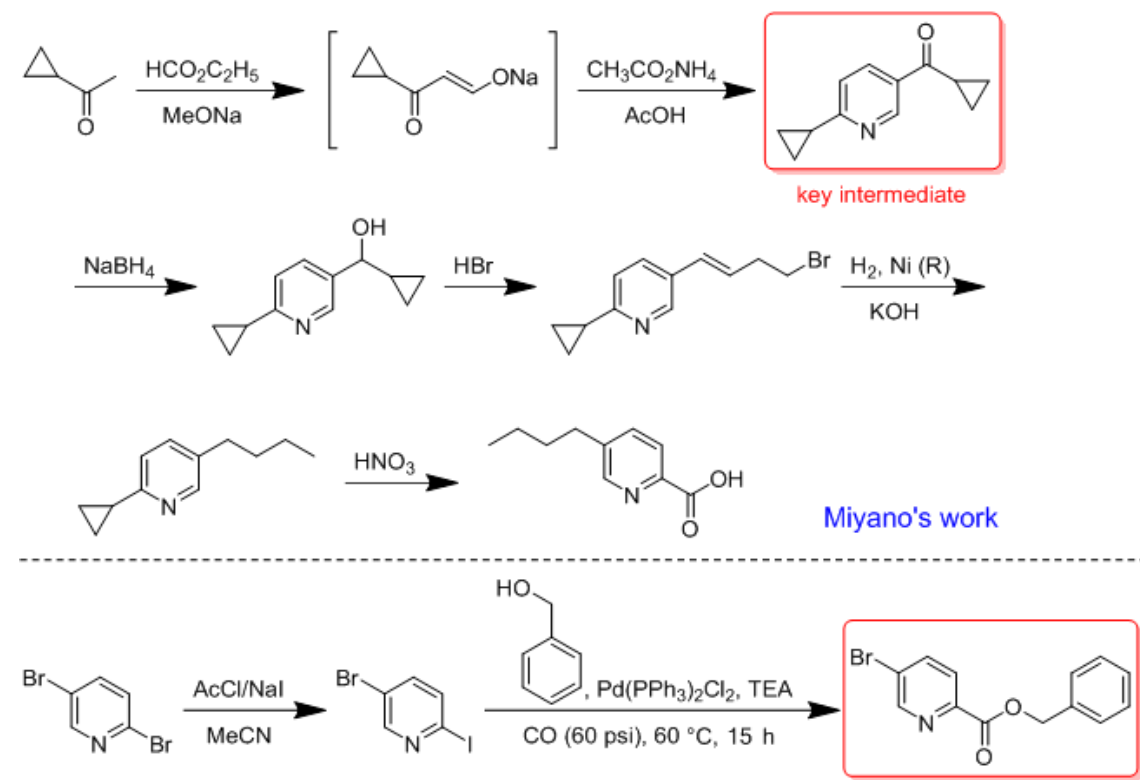

key intermediate

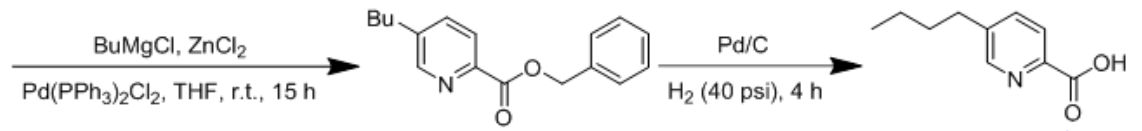

Song's work

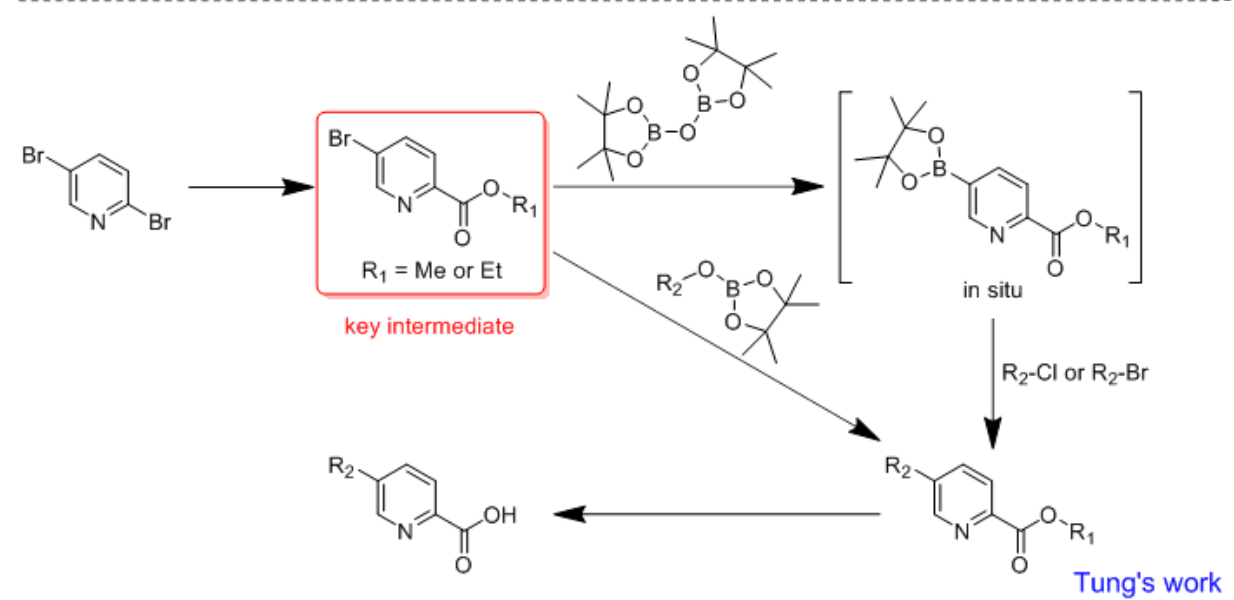

Scheme 2. Previous work for total synthesis of FA by elaborating substituted pyridine intermediate.

We envisioned that the sequential reactions, such as Wittig and carbonylation reactions, at $\mathrm{C}(2)$ and $C(5)$ positions of the pyridine ring would enable us to establish a concise and flexible route to a range of FA and its derivatives from a template 6-bromonicotinaldehyde, the commercially available compound (Scheme 3).

The objective of this study was to develop a concise, practical and scalable synthesis of FA and to facilitate further determinations of the FA inhibitory activities against several plant pathogenic fungi. In the meantime, we wish to reveal the great potential which FA has for further developing as an agricultural fungicide. 
<smiles>CCCCc1ccc(C(=O)O)nc1</smiles>

fusaric acid (1)<smiles>CCCCc1ccc(C(=O)OC)nc1</smiles>
2

Hydrogenation

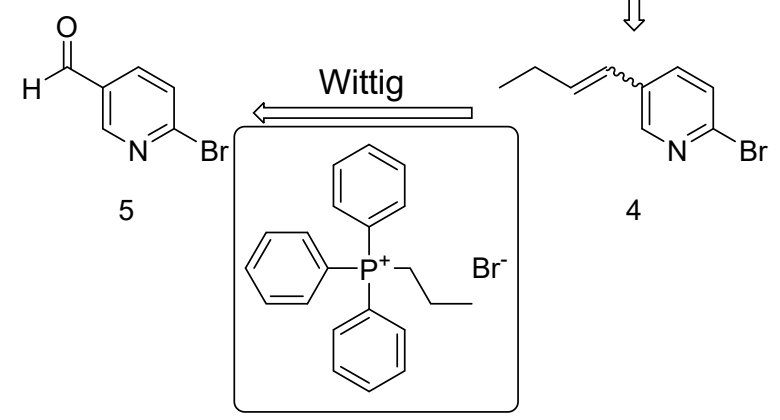

Scheme 3. Synthetic plan for FA.

\section{Results and Discussion}

\subsection{Total Synthesis of FA}

Our synthesis (Scheme 4) began with the preparation of 2-bromo-5-(but-1-en-1-yl)pyridine (4) from commercially available 6-bromonicotinaldehyde (5) and n-propyltriphenyl-phosphonium bromide by using the Wittig reaction [30], followed by a hydrogenation reaction [31] to afford 2-bromo-5-butylpyridine (3). Once 2-bromo-5-butylpyridine (3) was in hand, a carbonylation reaction [32] was carried out immediately and methyl 5-butylpicolinate (2) was obtained. To our delight, all the reactions had run very well and afforded the expected end-product FA (1) in high yield after a saponification reaction [33]. It is noteworthy that the synthetic route is reliable, practical and gram scale for the desired FA (1), of which the total yield was 58\% over only four steps and all spectroscopic data for our synthetic samples were in good agreement with those reported for the corresponding natural products.

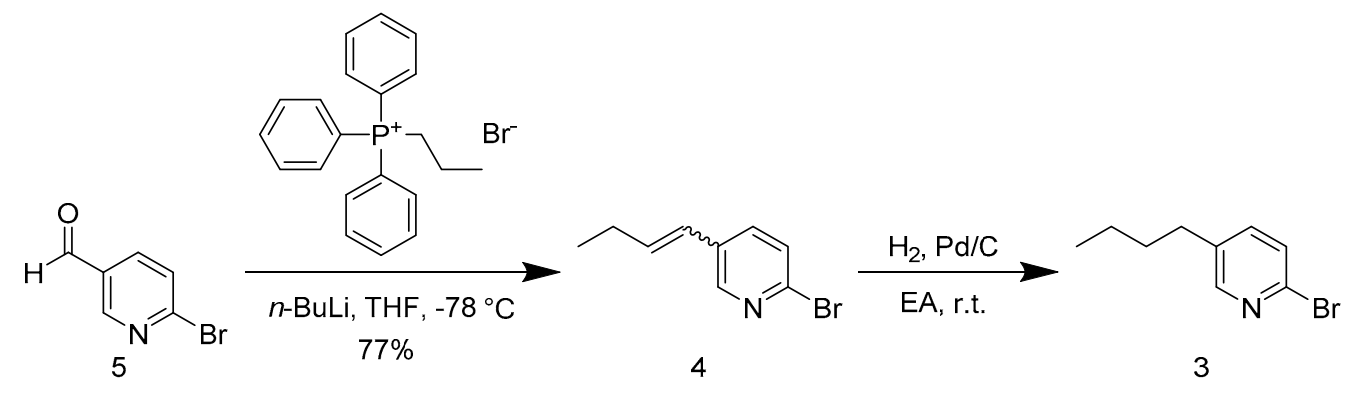

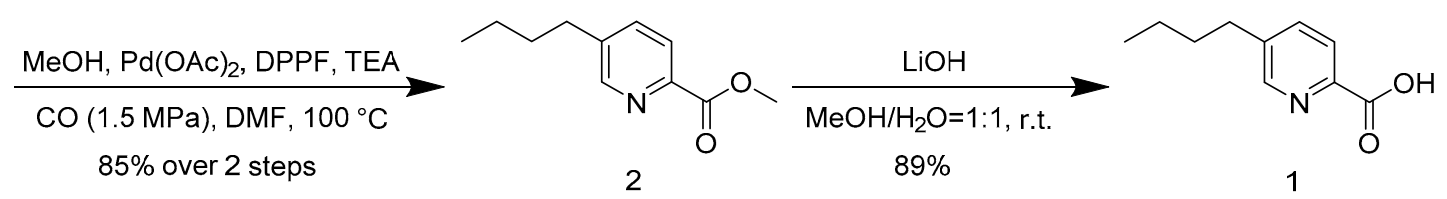

Scheme 4. Total synthesis of FA. 
Another simple method of preparing carboxylic acid by halogenated hydrocarbon is to introduce the cyano group through the reaction of halogenated hydrocarbon [34] or diazonium salt [35] with inorganic cyanide before hydrolysis [36]. However, the use of hazardous chemicals such as diazonium salts or inorganic cyanide is unavoidable. In this study, the methyl ester of FA was prepared by carbonylation reaction of halogenated hydrocarbons. Although the reaction requires palladium catalyst and pressure, it is a feasible process route for practical and scalable preparation at one time, especially if industrial production was required.

Additionally, since $n$-butyl lithium was used in the Wittig reaction, the reaction should be carried out at $-78{ }^{\circ} \mathrm{C}$, which may have adverse effects on the scale-up production. This step of the reaction was also explored preliminarily. When anhydrous dimethyl formamide (DMF) was used as solvent and $n$-butyl lithium was replaced by sodium hydride $(\mathrm{NaH})$, the dehydrogenation reaction could be carried out at $-10^{\circ} \mathrm{C}$, and the yield of 2-bromo-5-(but-1-en-1-yl)pyridine (4) was about $65 \%$.

\subsection{In Vitro Inhibitory Activities of FA against 14 Plant Pathogenic Fungi}

The results in Table 1 show that FA had a wide range of inhibitory activities against 14 plant pathogenic fungi, although the inhibition rates of FA against Valsa mal and Alternaria longipes at $200 \mu \mathrm{g} / \mathrm{mL}$ were only $12.93 \pm 1.18 \%$ and $28.57 \pm 2.04 \%$, respectively. Moreover, FA had the best inhibitory activities against Thanatephorus cucumeris, Colletotrichum higginsianum and Colletotrichum gloeosporioides, whose $50 \%$ effective concentration $\left(\mathrm{EC}_{50}\right)$ were $22.42,31.67$ and $90.80 \mu \mathrm{g} / \mathrm{mL}$, respectively.

Table 1. Toxicity of FA against 14 plant pathogenic fungi.

\begin{tabular}{|c|c|c|c|}
\hline Plant Pathogenic Fungus & $\mathrm{EC}_{50}(95 \% \mathrm{CL})(\mu \mathrm{g} / \mathrm{mL})$ & $\begin{array}{l}\text { Toxic Regression } \\
\text { Equation }\end{array}$ & $\begin{array}{c}\text { Determination } \\
\text { Coefficient }\end{array}$ \\
\hline Colletotrichum higginsianum & 31.67 (26.72-37.30) & $y=1.954 x+2.068$ & 0.9462 \\
\hline Helminthosporium maydis & $130.25(115.68-149.24)$ & $y=1.666 x+1.476$ & 0.9703 \\
\hline Pyricularia grisea & 120.39 (107.26-137.04) & $y=1.684 x+1.497$ & 0.9999 \\
\hline Thanatephorus cucumeris & $22.42(10.20-34.24)$ & $y=1.334 x+3.199$ & 0.9417 \\
\hline Botrytis cinerea & $338.10(258.80-484.10)$ & $y=1.166 x+2.051$ & 0.9806 \\
\hline Gliocladium catenulatum & 241.31 (193.89-367.29) & $y=2.726 x-1.494$ & 0.9990 \\
\hline Colletotrichum gloeosporioides & $90.80(60.23-171.70)$ & $y=0.969 x+3.103$ & 0.9745 \\
\hline $\begin{array}{c}\text { Pythium aphanidermatum } \\
\text { Valsa mal }\end{array}$ & $173.46(150.11-210.84)$ & $\begin{aligned} y= & 1.616 x+1.382 \\
& -\end{aligned}$ & 0.9897 \\
\hline Mycosphaerella arachidis & $187.60(174.98-203.80)$ & $y=3.941 x-3.959$ & 0.9530 \\
\hline Sclerotinia sclerotiorum & 190.68 (158.70-262.93) & $y=2.703 x-1.163$ & 0.9969 \\
\hline Phytophthora capsici & 170.89 (147.58-208.44) & $y=1.570 x+1.494$ & 0.9812 \\
\hline Rhizoctonia solani & 221.17 (174.97-358.79) & $y=2.695 x-1.318$ & 0.9893 \\
\hline Alternaria longipes & & - & \\
\hline
\end{tabular}

\section{Materials and Methods}

\subsection{General}

Reactions were carried out in flame- or oven-dried glassware under an argon atmosphere, unless otherwise noted. Tetrahydrofuran (THF) was freshly distilled before use from sodium using benzophenone as an indicator. All other anhydrous solvents were dried over 3 or $4 \AA$ molecular sieves. The solvents used in workup, extraction, and column chromatography were used as received from commercial suppliers without prior purification. Reactions were magnetically stirred and monitored by thin layer chromatography (TLC, $0.25 \mathrm{~mm}$ ) on pre-coated silica gel plates produced by Yantai Jiangyou silica gel Development Co., Ltd. (Yantai, Shandong Province, China). Flash chromatography was performed with silica gel 60 (particle size 0.040-0.062 mm) supplied by Qingdao Haiyang Chemical Co., Ltd. (Qingdao, Shandong Province, China). High resolution mass spectra were measured at Keecloud Mass Spectrometry Service Company, (Shanghai, China), on an Thermo Scientific LTQ Orbitrap XL system, Waltham, MA, USA. ${ }^{1} \mathrm{H}$ and ${ }^{13} \mathrm{C}-\mathrm{NMR}$ spectra were recorded on a Bruker AVIII-400 
spectrometer (400 MHz for ${ }^{1} \mathrm{H}, 100 \mathrm{MHz}$ for ${ }^{13} \mathrm{C}$ ), (Rheinstetten, German). Chemical shifts were reported in parts per million (ppm) as values relative to the internal chloroform $\left(7.26 \mathrm{ppm}\right.$ for ${ }^{1} \mathrm{H}$ and 77.16 ppm for ${ }^{13} \mathrm{C}$ ). Abbreviations for signal coupling are as follows: $s$, singlet; $d$, doublet; $t$, triplet; $q$, quartet; $\mathrm{m}$, multiplet. The visualization of NMR spectra could be found in the Supplementary Materials.

\subsection{Total Synthesis of FA}

\subsubsection{Synthesis of 2-Bromo-5-(but-1-en-1-yl)pyridine (4)}

To a solution of $n$-propyltriphenyl-phosphonium bromide $(9.25 \mathrm{~g}, 24.0 \mathrm{mmol})$ in anhydrous THF $(25 \mathrm{~mL})$ was added $n$-butyllithium $\left(13.75 \mathrm{~mL}, 22.0 \mathrm{mmol}, 1.6 \mathrm{M}\right.$ in hexane) dropwise at $-78^{\circ} \mathrm{C}$ and under an argon atmosphere. The reaction mixture was stirred for $15 \mathrm{~min}$ and then heated to $0^{\circ} \mathrm{C}$ for at least $1 \mathrm{~h}$. After the reaction mixture was cooled to $-78^{\circ} \mathrm{C}$, the solution dissolved 6-bromonicotinaldehyde (5) $(3.72 \mathrm{~g}, 20.0 \mathrm{mmol})$ in anhydrous THF $(25 \mathrm{~mL})$ was added. It was stirred for $15 \mathrm{~min}$ and then heated to room temperature (RT); the reaction mixture was stirred at RT until the complete consumption of starting material was observed by TLC $(3 \mathrm{~h})$. Aqueous saturated ammonium chloride $\left(\mathrm{NH}_{4} \mathrm{Cl}\right)$ solution $(10 \mathrm{~mL})$ was added under vigorous stirring to quench the reaction. The volatiles (mainly THF) were removed under reduced pressure and the aqueous phase was extracted with dichloromethane $(3 \times 20 \mathrm{~mL})$. The combined organic fractions were washed with water and brine, dried over anhydrous sodium sulfate $\left(\mathrm{Na}_{2} \mathrm{SO}_{4}\right)$ and evaporated under reduced pressure. The residue was purified by flash column chromatography on silica gel using eluents (petroleum ether/ethyl acetate $=20 / 1$ ) to afford 2-bromo-5-(but-1-en-1-yl)pyridine (4) as a colorless oil (3.28 g, 77\% yield). Major diastereomer. ${ }^{1} \mathrm{H}-\mathrm{NMR}\left(400 \mathrm{MHz}, \mathrm{CDCl}_{3}\right) \delta 8.26(\mathrm{~s}, 1 \mathrm{H}), 7.45-7.43(\mathrm{~m}, 2 \mathrm{H}), 6.26(\mathrm{dt}, J=11.6,1.5 \mathrm{~Hz}, 1 \mathrm{H}), 5.83(\mathrm{dt}$, $J=11.6,7.4 \mathrm{~Hz}, 1 \mathrm{H}), 2.31-2.25(\mathrm{~m}, 2 \mathrm{H}), 1.06(\mathrm{t}, J=7.5 \mathrm{~Hz}, 3 \mathrm{H}) .{ }^{13} \mathrm{C}-\mathrm{NMR}\left(100 \mathrm{MHz}, \mathrm{CDCl}_{3}\right) \delta 150.1$, 139.7, 138.4, 138.1, 132.7, 127.6, 123.5, 22.1, 14.3. Minor diastereomer. ${ }^{1} \mathrm{H}-\mathrm{NMR}\left(400 \mathrm{MHz}, \mathrm{CDCl}_{3}\right) \delta$ $8.29(\mathrm{~d}, J=2.5 \mathrm{~Hz}, 1 \mathrm{H}), 7.53(\mathrm{dd}, J=8.1,2.5 \mathrm{~Hz}, 1 \mathrm{H}), 7.40(\mathrm{~d}, J=8.1,1 \mathrm{H}), 6.39-6.29(\mathrm{~m}, 2 \mathrm{H}), 2.25-2.21$ $(\mathrm{m}, 2 \mathrm{H}), 1.11-1.10(\mathrm{~m}, 3 \mathrm{H}) .{ }^{13} \mathrm{C}-\mathrm{NMR}\left(100 \mathrm{MHz}, \mathrm{CDCl}_{3}\right) \delta 148.1,139.7,136.3,135.1,133.0,127.9,124.1$, $26.3,13.4$.

\subsubsection{Synthesis of 2-Bromo-5-butylpyridine (3)}

A round bottom flask was charged with 2-bromo-5-(but-1-en-1-yl)pyridine (4) (3.28 g, $15.5 \mathrm{mmol})$, then evacuated and backfilled with argon. After ethyl acetate $(30 \mathrm{~mL})$ and $10 \% \mathrm{Pd} / \mathrm{C}(1.65 \mathrm{~g}, 1.55 \mathrm{mmol})$ were added under argon, the argon in the round bottom flask was replaced by hydrogen for at least $10 \mathrm{~min}$. It was stirred at RT under a hydrogen atmosphere until the complete consumption of starting material was observed by TLC ( $15 \mathrm{~min})$. The resulting suspension was filtered through a compacted diatomaceous earth layer eluting with dichloromethane $(3 \times 20 \mathrm{~mL})$. The combined filtrate was collected and evaporated under reduced pressure to afford a colorless oil. It was used directly as crude (3) in the next step immediately.

\subsubsection{Synthesis of Methyl 5-butylpicolinate (2)}

The crude (3), palladium (II) acetate $(0.067 \mathrm{~g}, 0.30 \mathrm{mmol}), 1,1^{\prime}$-Bis(diphenylphosphino)ferrocene (DPPF; $0.333 \mathrm{~g}, 0.60 \mathrm{mmol}$ ), trimethylamine (TEA; $2.98 \mathrm{~g}, 29.5 \mathrm{mmol}$ ) and methanol (12 mL, $294.8 \mathrm{mmol}$ ) were dissolved in DMF (30 mL) and the solution was stirred under carbon monoxide (CO; $1.5 \mathrm{MPa})$ at $100{ }^{\circ} \mathrm{C}$ overnight. The reaction mixture was cooled to RT before most of the volatile components were removed under reduced pressure. Saturated sodium chloride $(\mathrm{NaCl})$ solution $(100 \mathrm{~mL})$ was added and then the mixture was shaken vigorously. The solution was extracted with ethyl acetate $(3 \times 30 \mathrm{~mL})$, and the combined organic layers were washed with water and brine, dried $\left(\mathrm{Na}_{2} \mathrm{SO}_{4}\right)$, filtered and concentrated by evaporating under reduced pressure. The resulting residue was purified by flash chromatography on silica gel using eluents (petroleum ether/ethyl acetate $=10 / 1$ ) to afford the desired methyl 5-butylpicolinate (2) (2.56 g, 85\% yield over 2 steps) as a colorless oil. ${ }^{1} \mathrm{H}-\mathrm{NMR}(400 \mathrm{MHz}$, $\left.\mathrm{CDCl}_{3}\right) \delta 8.55(\mathrm{~d}, J=1.8 \mathrm{~Hz}, 1 \mathrm{H}), 8.05(\mathrm{~d}, J=8.0 \mathrm{~Hz}, 1 \mathrm{H}), 7.64(\mathrm{dd}, J=8.0,1.8 \mathrm{~Hz}, 1 \mathrm{H}), 3.99(\mathrm{~s}, 3 \mathrm{H}), 2.68$ 
$(\mathrm{t}, J=7.6 \mathrm{~Hz}, 2 \mathrm{H}), 1.67-1.56(\mathrm{~m}, 2 \mathrm{H}), 1.42-1.30(\mathrm{~m}, 2 \mathrm{H}), 0.93(\mathrm{t}, J=7.3 \mathrm{~Hz}, 3 \mathrm{H}) .{ }^{13} \mathrm{C}-\mathrm{NMR}(100 \mathrm{MHz}$, $\left.\mathrm{CDCl}_{3}\right) \delta 165.9,150.1,145.6,142.4,136.8,125.1,52.9,33.1,32.9,22.3,13.9$.

\subsubsection{Synthesis of FA (1)}

Methyl 5-butylpicolinate (2) $(2.56 \mathrm{~g}, 13.2 \mathrm{mmol})$ was mixed with lithium hydrate (LiOH; $1.58 \mathrm{~g}$, $66.0 \mathrm{mmol})$ in a $30 \mathrm{~mL}$ methanol/water $(v / v=1: 1)$ mixed solvent, and then it was stirred at RT. After TLC analysis indicated complete consumption of the starting material $(1 \mathrm{~h})$, the volatiles (mainly methanol) were removed under reduced pressure. The $\mathrm{pH}$ of the resulting suspension was adjusted to about 2 with $1.0 \mathrm{M} \mathrm{HCl}$. The aqueous phase was extracted with dichloromethane until no product was observed in the aqueous phase by TLC. The combined organic layers were dried over anhydrous $\mathrm{Na}_{2} \mathrm{SO}_{4}$, filtered and evaporated under reduced pressure. The desired FA (1) was obtained as a white solid (2.12 g, 89\% yield). Mp $=99-101^{\circ} \mathrm{C}$. (lit. 99-100.5 ${ }^{\circ} \mathrm{C}$ ) [22] ${ }^{1} \mathrm{H}-\mathrm{NMR}$ and ${ }^{13} \mathrm{C}-\mathrm{NMR}$ of the synthetic material were identical to those reported for the natural product [22]: ${ }^{1} \mathrm{H}-\mathrm{NMR}\left(400 \mathrm{MHz}, \mathrm{CDCl}_{3}\right)$ $\delta 10.79(\mathrm{~s}, 1 \mathrm{H}), 8.59(\mathrm{~s}, 1 \mathrm{H}), 8.15(\mathrm{~d}, J=7.8 \mathrm{~Hz}, 1 \mathrm{H}), 7.73(\mathrm{~d}, J=7.5 \mathrm{~Hz}, 1 \mathrm{H}), 2.70(\mathrm{t}, J=7.5 \mathrm{~Hz}, 2 \mathrm{H})$, 1.73-1.51 (m, 2H), 1.45-1.25 (m, 2H), $0.92(\mathrm{t}, J=7.3 \mathrm{~Hz}, 3 \mathrm{H}) .{ }^{13} \mathrm{C}-\mathrm{NMR}\left(100 \mathrm{MHz}, \mathrm{CDCl}_{3}\right) \delta 165.8,148.1$, $145.2,143.1,138.4,124.4,33.1,32.9,22.4,13.9$. HRMS (ESI) $m / z$ calculated for $\mathrm{C}_{10} \mathrm{H}_{13} \mathrm{NO}_{2}[\mathrm{M}+\mathrm{H}]^{+}$ 180.10191, found 180.10147 .

\subsection{In Vitro Inhibitory Activities of FA against 14 Plant Pathogenic Fungi}

The antifungal activities were evaluated against 14 pathogenic fungi, namely, C. higginsianum, H. maydis, P. grisea, T. cucumeris, B. cinerea, G. catenulatum, C. gloeosporioides, P. aphanidermatum, V. mal, M. arachidis, S. sclerotiorum, P. capsici, R. solani, and A. longipes, by the poison plate technique [37-39]. FA was dissolved in chromatographic grade methanol $(2 \mathrm{~mL})$ to prepare a $10 \mathrm{mg} / \mathrm{mL}$ stock solution. A proper amount of stock solution was precisely transferred with a pipette, and mixed with sterilized and melted potato dextrose agar (PDA; $49 \mathrm{~mL}$ ). The corresponding amount of chromatographic grade methanol and sterile distilled water were added to make the total volume of $50 \mathrm{~mL}$ with $2 \%$ methanol content. FA was tested at five double-declining concentrations (e.g., 200, 100, 50, 25, and $12.5 \mu \mathrm{g} / \mathrm{mL}$ ). Meantime, all fungi were cultivated in PDA at $28.0 \pm 0.5{ }^{\circ} \mathrm{C}$ for 5 days in darkness to make new mycelium for the identification of antifungal activity. Then, mycelia dishes of approximately $5 \mathrm{~mm}$ diameter were cut from the culture medium. A mycelium was obtained using a germ-free inoculation needle and inoculated reversely in the center of the PDA plate aseptically. The inoculated plates were incubated at $28.0 \pm 0.5^{\circ} \mathrm{C}$ for $2-7$ days in darkness. Chromatographic-grade methanol in sterile distilled water served as the control. At least three biological replicates and controls were used for each concentration. Radial growth of the fungal colonies was measured, and the data were statistically analyzed. Inhibitory activities of FA in vitro on these fungi were calculated by the formula $\mathrm{I}(\%)=[(\mathrm{C}-\mathrm{T}) /(\mathrm{C}-5.00)] \times 100$, where $\mathrm{C}$ represents the diameter of fungal growth on untreated PDA (blank PDA with $2 \%$ methanol), T represents the diameter of fungal growth on treated PDA, and I represents the inhibition rate. Finally, the corresponding toxic regression equation, $\mathrm{EC}_{50}$, $95 \%$ confidence interval and determination coefficient were obtained by using the software package SPSS 22.0.

\section{Conclusions}

In summary, we have developed a total synthesis of naturally occurring alkaloid FA in four steps with a 58\% yield from 6-bromonicotinaldehyde (5), by taking advantage of Wittig reaction, hydrogenation, carbonylation and saponification. The synthesis is concise, convergent, practical and can be carried out on a two-gram scale. Since this synthesis is based on a unified and flexible strategy using 6-bromonicotinaldehyde (5) as a common intermediate, it is readily applicable to analogue synthesis. Furthermore, the results from in vitro antifungal activities of FA reveal that FA, as a leading compound, has great potential to be further researched and developed as an agricultural fungicide. Further exploration of the strategy for the generation of novel analogues for biological evaluation is 
ongoing in our laboratory. As a kind of phytotoxin, FA can cause some plants to wilt or inhibit root elongation, such as bananas [40,41], tomatoes [13], tobacco [42,43], maize [44], and watermelons [45,46], etc. In order to ensure the plants of agricultural interest being safe, novel FA analogues for further biological evaluation should be evaluated as to whether the analogues might cause phytotoxicity at an effective dose. Relevant study work is also ongoing in our laboratory.

Supplementary Materials: The following are available online. Copies of ${ }^{1} \mathrm{H}$ and ${ }^{13} \mathrm{C}$ of new compounds.

Author Contributions: Conceived and designed the experiments: M.-A.O. and B.B.H. Wrote the paper: B.B.H. Performed the experiments: B.B.H., Y.Y.L., P.F.Z. and Y.C.J. Contributed reagents/materials/analysis tools/scientific funds: M.-A.O. and B.B.H. All authors have read and agreed to the published version of the manuscript.

Funding: This study was supported by the Educational and Scientific Research Project for Young and Middle-aged Teachers of Education Department of Fujian Province (No. JAT170167). The funder had no role in study design, data collection and analysis, decision to publish, or preparation of the manuscript.

Acknowledgments: The authors are grateful for the financial support from the funding.

Conflicts of Interest: The authors report no conflict of interest.

\section{References}

1. Zhao, J.-H.; Li, J.-Z. A Progress on the study of the agricultural microbial fungicides. Pesticides 2003, 42, 8-10.

2. Hollomon, D.-W. Fungicide resistance: Facing the challenge. Plant Prot. Sci. 2015, 51, 170-176. [CrossRef]

3. Wang, H.; Ng, T.-B. Pharmacological activities of fusaric acid (5-butylpicolinic acid). Life Sci. 1999, 65, 849-856. [CrossRef]

4. Yabuta, T. Biochemistry of Fusarium heterosporium in rice plant, Part 1: Newly found product of fusaric acid. J. Agric. Chem. Soc. Jpn. 1934, 10, 1059-1068.

5. Furuta, Y.; Washizaki, M. Effects of fusaric acid and its derivative on the cardiovascular system. Folia Pharm. Jpn. 1976, 72, 139-144. [CrossRef]

6. Terasawa, F.; Ying, L.-H.; Kameyama, M. The hypotensive effect of fusaric acid: The results of long-term administration of fusaric acid in elderly hypertensive patients. Jpn. Circ. J. 1976, 40, 1017-1023. [CrossRef]

7. Fernandez-Pol, J.-A.; Klos, D.-J.; Hamilton, P.-D. Antiviral, cytotoxic and apoptotic activities of picolinic acid on human immunodeficiency virus-1 and human herpes simplex virus-2 infected cells. Anticancer Res. 2001, 21, 3773-3776.

8. $\quad$ Li, J.-F.; Sun, W.-Y.; Guo, Z.-X.; Lu, C.-H.; Shen, Y.-M. Fusaric acid modulates type three secretion system of Salmonella enterica serovar Typhimurium. Biochem. Biophys. Res. Commun. 2014, 449, 455-459. [CrossRef]

9. Vesonder, R.-F.; Gasdorf, H.; Peterson, R.-E. Comparison of the cytotoxicities of Fusarium metabolites and Alternaria metabolite AAL-toxin to cultured mammalian cell lines. Arch. Environ. Contam. Toxicol. 1993, 24, 473-477. [CrossRef]

10. Fernandez-Pol, J.-A.; Klos, D.-J.; Hamilton, P.-D. Cytotoxic activity of fusaric acid on human adenocarcinoma cells in tissue culture. Anticancer Res. 1993, 13, 57-64.

11. Herskovits, E.; Figueroa, G.-E. Effect of fusaric acid in Parkinson's disease. Medicine 1973, 33, 51.

12. Chase, T.-N. Fusaric acid in Parkinson's disease. Neurology 1974, 24, 637-639. [CrossRef] [PubMed]

13. Capasso, R.; Evidente, A.; Cutignano, A.; Vurro, M.; Zonno, M.-C.; Bottalico, A. Fusaric and 9, 10-dehydrofusaric acids and their methyl esters from Fusarium nygamai. Phytochemistry 1996, 41, 1035-1039. [CrossRef]

14. Stipanovic, R.-D.; Puckhaber, L.-S.; Liu, J.; Bell, A.-A. Phytotoxicity of fusaric acid and analogs to cotton. Toxicon 2011, 57, 176-178. [CrossRef] [PubMed]

15. Dowd, P.-F. Relative inhibition of insect phenoloxidase by cyclic fungal metabolites from insect and plant pathogens. Nat. Toxins 1999, 7, 337-341. [CrossRef]

16. Kwon, H.-R.; Son, S.-W.; Han, H.-R.; Choi, G.-J.; Jang, K.-S.; Choi, Y.-H.; Lee, S.; Sung, N.-D.; Kim, J.-C. Nematicidal activity of bikaverin and fusaric acid isolated from Fusarium oxysporum against pine wood nematode, Bursaphelenchus xylophilus. Plant Pathol. J. 2007, 23, 318-321. [CrossRef]

17. Zheng, Y.; Wu, B.; Chen, Y.-W. Active ingredients from metabolite of Datura arborea entophytic fungi and its anti-dermal pathogenic fungi activities. J. Anhui Agric. Sci. 2011, 39, 1323-1324, 1329. 
18. Son, S.-W.; Kim, H.-Y.; Choi, G.-J.; Lim, H.-K.; Jang, K.-S.; Lee, S.-O.; Lee, S.; Sung, N.-D.; Kim, J.-C. Bikaverin and fusaric acid from Fusarium oxysporum show antioomycete activity against Phytophthora infestans. J. Appl. Microbiol. 2008, 104, 692-698. [CrossRef]

19. Waldner, A. A short synthesis of fusaric acid and analogues. Synth Commun. 1989, 19, 2371-2374. [CrossRef]

20. Sagi, M.; Amano, M.; Konno, S.; Yamanaka, H. Studies on as-triazine derivatives. XIII: A facile synthesis of fusaric acid from thienyl-as-triazine derivative. Heterocycles (Sendai) 1989, 29, 2249-2252.

21. Koyama, J.; Ogura, T.; Tagahara, K. Diels-Alder reaction of 1, 2, 3-triazine with aldehyde enamine. Heterocycles (Sendai) 1994, 38, 1595-1600. [CrossRef]

22. Renslo, A.-R.; Danheiser, R.-L. Synthesis of substituted pyridines via regiocontrolled [4 + 2] cycloadditions of oximinosulfonates. J. Org. Chem. 1998, 63, 7840-7850. [CrossRef]

23. Vogt, H.; Mayer, H. Eine neue synthese der fusarinsäure. Tetrahedron Lett. 1966, 7, 5887-5888. [CrossRef]

24. Tschesche, R.; Führer, W. Eine neue Synthese der 5-Butyl-2-pyridincarbonsäure (Fusarsäure) über die „Emmert-Reaktion". Chem. Ber. 1978, 111, 3502-3505. [CrossRef]

25. Langhals, E.; Langhals, H.; Rüchardt, C. Eine einfache neue synthese der fusarinsäure und anderer 5-Alkyl-2-pyridincarbonsäuren. Liebigs Ann. Chem. 1982, 930-949. [CrossRef]

26. Miyano, K.; Sakasai, T.; Hamano, H. Synthesis of 5-(substituted alkyl) picolinic acids. the dopamine $\beta$-hydroxylase inhibitors. II. Chem. Pharm. Bull. 1978, 26, 2328-2333. [CrossRef]

27. Song, J.-J.; Yee, N.-K. A concise synthesis of fusaric acid and-(+)-fusarinolic acid. J. Org. Chem. 2001, 66, 605-608. [CrossRef]

28. Tung, T.-T.; Jakobsen, T.-H.; Dao, T.-T.; Fuglsang, A.-T.; Givskov, M.; Christensen, S.-B.; Nielsen, J. Fusaric acid and analogues as Gram-negative bacterial quorum sensing inhibitors. Eur. J. Med. Chem. 2017, 126, 1011-1020. [CrossRef]

29. Chumakov, Y.-I.; Sherstyuk, V.-P. The synthesis of the fusarinic acid, its isomers and homologues. Tetrahedron Lett. 1965, 6, 129-135. [CrossRef]

30. Shing, K.-P.; Liu, Y.-G.; Cao, B.; Chang, X.-T.; You, T.-J.; Che, C.-M. N-Heterocyclic Carbene Iron (III) Porphyrin-Catalyzed Intramolecular C (sp3)-H Amination of Alkyl Azides. Angew. Chem. Int. Ed. 2018, 57, 11947-11951. [CrossRef]

31. Brenna, E.; Cosi, S.-L.; Ferrandi, E.-E.; Gatti, F.-G.; Monti, D.; Parmeggiani, F.; Sacchetti, A. Substrate scope and synthetic applications of the enantioselective reduction of $\alpha$-alkyl- $\beta$-arylenones mediated by Old Yellow Enzymes. Org. Biomol. Chem. 2013, 11, 2988-2996. [CrossRef] [PubMed]

32. Rabal, O.; Sánchez-Arias, J.-A.; Cuadrado-Tejedor, M.; De Miguel, I.; Pérez-González, M.; García-Barroso, C.; Ana Ugarte, A.; De Mendoza, A.-E.-H.; Sáez, E.; Espelosin, M.; et al. Multitarget approach for the treatment of Alzheimer's disease: Inhibition of Phosphodiesterase 9 (PDE9) and Histone Deacetylases (HDACs) covering diverse selectivity profiles. ACS Chem. Neurosci. 2019, 10, 4076-4101. [CrossRef] [PubMed]

33. Shyaka, C.; Xian, M.; Park, C.-M. Esterase-sensitive trithiane-based hydrogen sulfide donors. Org. Biomol. Chem. 2019, 17, 9999-10003. [CrossRef] [PubMed]

34. Schareina, T.; Zapf, A.; Cotté, A.; Müller, N.; Beller, M. A bio-inspired copper catalyst system for practical catalytic cyanation of aryl bromides. Synthesis 2008, 2008, 3351-3355. [CrossRef]

35. Barbero, M.; Degani, I.; Dughera, S.; Fochi, R. Hydrodediazoniation of dry arenediazonium o-benzenedisulfonimides with hydrogen peroxide. Synthesis 2004, 2004, 2386-2390. [CrossRef]

36. Kumar, S.; Dixit, S.-K.; Awasthi, S.-K. An efficient one pot method for synthesis of carboxylic acids from nitriles using recyclable ionic liquid [bmim] $\mathrm{HSO}_{4}$. Tetrahedron Lett. 2014, 55, 3802-3804. [CrossRef]

37. Chattapadhyay, T.-K.; Dureja, P. Antifungal activity of 4-methyl-6-alkyl-2H-pyran-2-ones. J. Agric. Food Chem. 2006, 54, 2129-2133. [CrossRef]

38. Xu, W.-M.; He, J.; He, M.; Han, F.-F.; Chen, X.-H.; Pan, Z.-X.; Wang, J.; Tong, M.-G. Synthesis and antifungal activity of novel sulfone derivatives containing 1,3,4-oxadiazole moieties. Molecules 2011, 16, 9129-9141. [CrossRef]

39. Wang, X.; Li, P.; Li, Z.-N.; Yin, J.; He, M.; Xue, W.; Chen, Z.-W.; Song, B.-A. Synthesis and bioactivity evaluation of novel arylimines containing a 3-aminoethyl-2-[( $p$-trifluoromethoxy)anilino]-4(3H)-quinazolinone moiety. J. Agric. Food Chem. 2013, 61, 9575-9582. [CrossRef]

40. Dong, X.; Ling, N.; Wang, M.; Shen, Q.-R.; Guo, S.-W. Fusaric acid is a crucial factor in the disturbance of leaf water imbalance in Fusarium-infected banana plants. Plant Physiol. Biochem. 2012, 60, 171-179. [CrossRef] 
41. Dong, X.; Xiong, Y.-F.; Ling, N.; Shen, Q.-R.; Guo, S.-W. Fusaric acid accelerates the senescence of leaf in banana when infected by Fusarium. World J. Microbiol. Biotechnol. 2014, 30, 1399-1408. [CrossRef]

42. Barna, B.; Györgyi, B. Resistance of young versus old tobacco leaves to necrotrophs, fusaric acid, cell wall-degrading enzymes and autolysis of membrane lipids. Physiol. Mol. Plant Pathol. 1992, 40, 247-257. [CrossRef]

43. Jiao, J.; Zhou, B.-G.; Zhu, X.-P.; Gao, Z.-L.; Liang, Y.-C. Fusaric acid induction of programmed cell death modulated through nitric oxide signalling in tobacco suspension cells. Planta 2013, 238, 727-737. [CrossRef] [PubMed]

44. Arias, J.-A. Secretory organelle and mitochondrial alterations induced by fusaric acid in root cells of Zea mays. Physiol. Plant Pathol. 1985, 27, 149-158. [CrossRef]

45. Wu, H.-S.; Yin, X.-M.; Zhu, Y.-Y.; Guo, S.-W.; Wu, C.-L.; Lu, Y.-L.; Shen, Q.-R. Nitrogen metabolism disorder in watermelon leaf caused by fusaric acid. Physiol. Mol. Plant Pathol. 2007, 71, 69-77. [CrossRef]

46. Wu, H.-S.; Yin, X.-M.; Liu, D.-Y.; Ling, N.; Bao, W.; Ying, R.-R.; Zhu, Y.-Y.; Guo, S.-W.; Shen, Q.-R. Effect of fungal fusaric acid on the root and leaf physiology of watermelon (Citrullus lanatus) seedlings. Plant Soil 2008, 308, 255-266. [CrossRef]

Sample Availability: Samples of the compounds 1, 2, 4 and 5 are available from the authors. 